\title{
Toxicity of acaricides to Raoiella indica and their selectivity for its predator, Amblyseius largoensis (Acari: Tenuipalpidae: Phytoseiidae)
}

\author{
Carla P. O. de Assis • Elisângela G. F. de Morais • Manoel G. C. Gondim Jr.
}

Received: 2 July 2012/Accepted: 30 November 2012/Published online: 11 December 2012

(C) Springer Science+Business Media Dordrecht 2012

\begin{abstract}
Raoiella indica Hirst (Acari: Tenuipalpidae) is considered a pest of coconut palm in Asia and the Middle East. This mite was recently introduced in the Americas, where it spread to several countries and expanded its range of hosts, causing heavy losses to coconut and banana production. The phytoseiid mite Amblyseius largoensis (Muma) is one of the predators most often encountered in coconut palms. Because the current prospects for the control of $R$. indica in the New World indicate the use of acaricides and the management of their natural enemies, the objective of this study was to evaluate the toxicity of selected acaricides to $R$. indica and the selectivity (i.e., toxicity to the predator relative to toxicity to the prey) for A. largoensis. Assays were performed by the immersion of banana leaf discs in acaricide solutions, followed by the placing of adult females of the pest or predator on the discs. Mortality of the mites was evaluated after $24 \mathrm{~h}$, and the data obtained were subjected to probit analysis. Abamectin, fenpyroximate, milbemectin and spirodiclofen were the products most toxic to $R$. indica adults, whereas fenpyroximate and spirodiclofen were the most selective for A. largoensis.
\end{abstract}

Keywords Palm tree $\cdot$ Banana tree $\cdot$ Phytoseiid $\cdot$ Chemical control $\cdot$ Integrated management

\section{Introduction}

The red palm mite, Raoiella indica Hirst (Tenuipalpidae), was first described in India (Hirst 1924). Since then, this mite has been reported in several countries in Asia, the Middle East and Africa (Carrillo et al. 2012). Roughly 8 years ago, this mite was found on

C. P. O. de Assis - M. G. C. Gondim Jr. ( $₫)$

Depto. de Agronomia, Universidade Federal Rural de Pernambuco, 52171-900 Recife, PE, Brazil

e-mail: mguedes@depa.ufrpe.br

E. G. F. de Morais

Laboratório de Entomologia, Embrapa Roraima, BR 174, Km 8, Distrito Industrial, Caixa Postal 133, 69301-970 Boa Vista, RR, Brazil

e-mail: elisangela.fidelis@gmail.com 
the French island of Martinique (Flechtmann and Etienne 2004) from which it rapidly spread to other Caribbean islands, Brazil, Colombia, USA, Mexico and Venezuela (Kane et al. 2005; Navia et al. 2011; Carrillo et al. 2012). In the Old World, $R$. indica has been found only on Arecaceae; however, in the New World, its range of hosts increased significantly, and it has been found developing and reproducing on species of Cannaceae, Heliconiaceae, Musaceae, Pandanaceae, Strelitziaceae and Zingiberaceae (Cocco and Hoy 2009; Navia et al. 2011; Carrillo et al. 2012). However, high populations in the New World have been observed only on palm and banana trees, where they cause a severe yellowing of the leaves followed by tissue necrosis (Flechtmann and Etienne 2004). Severe attacks of this mite on coconut palms (Cocos nucifera L.) have caused significant reductions in fruit production (Navia et al. 2011).

The control of $R$. indica has been investigated in areas where it has recently been introduced. Such practices as plant resistance (Rodrigues and Irish 2012), chemical control (Rodrigues and Peña 2012) and biological control (Peña et al. 2009; Carrillo et al. 2010, 2012; Carrillo and Peña 2012; Hoy 2012) have been previously explored. Investigations on the potential of natural enemies of $R$. indica have also been performed, particularly with Amblyseius largoensis (Muma) (Acari: Phytoseiidae) (Peña et al. 2009; Carrillo et al. 2010, 2012; Carrillo and Peña 2012).

Much information on the effectiveness of acaricides in the control of $R$. indica was obtained from field studies in India and the Middle East (Sarkar and Somchoudhury 1988; Jalaluddin and Mohanasundaram 1990; Jayaraj et al. 1991). However, the majority of the acaricides evaluated in those studies referred to products that are no longer allowed to be used in Brazil. In this country, the distribution of $R$. indica is restricted to the northern region, in the states of Roraima (Navia et al. 2011) and Amazonas (Rodrigues and Antony 2011). Although the Amazon rainforest predominates in these states, the crops of banana and both exotic and native Arecaceae, for example, açaí, moriche palm (buriti) and peachpalm, play important economic and social roles, particularly for low-income populations. The problems that $R$. indica may cause in this region should be considered along with its possible spread to the Brazilian northeast, where the majority of coconut palms in Brazil are located. A much more significant impact may occur in the northeast region with potentially serious consequences.

Because investigations on the potential of native and exotic natural enemies in Brazil have not reached any conclusive results, it is necessary to obtain information regarding the effectiveness of other control methods, permitting their use in emergency situations. The objective of this study was to evaluate the toxicity of selected acaricides to $R$. indica and the selectivity for A. largoensis under laboratory conditions.

\section{Materials and methods}

Collection and maintenance of Raoiella indica and Amblyseius largoensis populations

The specimens of $R$. indica used in this study were collected from colonies that were initiated with mites collected from Adonidia merrillii (Becc.) Becc. (=Veitchia) (Arecaceae) in Boa Vista, Roraima, Brazil $\left(2^{\circ} 45^{\prime} 29.1^{\prime \prime} \mathrm{N}, 60^{\circ} 43^{\prime} 51.6^{\prime \prime} \mathrm{W}\right)$. The colonies were established into plastic dishes measuring $16 \mathrm{~cm}$ in diameter containing a banana leaf disc on a piece of polyethylene foam measuring $1.0 \mathrm{~cm}$ in thickness. The border of each disc was covered with a layer of hydrophilic cotton, and the foam and cotton were kept saturated with distilled water to prevent the escape of the mites. These units were 
maintained inside growth chamber at $27 \pm 0.5{ }^{\circ} \mathrm{C}, 80 \pm 10 \%$ relative humidity and a $12 \mathrm{~h}$ photoperiod. The specimens of A. largoensis used in the study were collected in the same location from coconut palm leaves and transferred to dishes infested with $R$. indica, as previously described. Castor bean (Ricinus communis L.) pollen was also added to feed the predator mites.

\section{Acaricides evaluated}

The acaricides evaluated were as follows: abamectin (Kraft 36 EC; Cheminova Brasil); chlorfenapyr (Pirate; Basf); diafenthiuron (Polo 500 WP; Syngenta Proteção de Cultivo); fenbutatin oxide (Torque $500 \mathrm{SC}$; Basf); fenpyroximate (Ortus 50 SC; Arysta Lifescience do Brasil Indústria Química e Agropecuária); hexythiazox (Talento; Du Pont do Brasil-Barueri); milbemectin (Milbeknock; Iharabras Chemical Industries); propargite (Omite 720 EC; Chemtura Indústria Química do Brasil); spirodiclofen (Envidor; Bayer, São Paulo, SP) and spiromesifen (Oberon 240 SC; Bayer CropScience).

\section{Experimental procedure}

\section{Preliminary tests}

Preliminary, tests were performed according to method No. 4 of the series of methods for susceptibility testing of the Insecticide Resistance Action Committee (IRAC 2003). Concentrations diluted by a factor of $10(0.01,0.1,1,10,100$ and $1,000 \mathrm{mg}$ of active ingredient per liter of solution) and a control (distilled water) were prepared for each acaricide. Each experimental unit corresponded to a banana leaf disc ( $5 \mathrm{~cm}$ in diameter) immersed for $5 \mathrm{~s}$ in one of the acaricide solution or water. The disc was allowed to dry at room temperature for $20 \mathrm{~min}$ and was placed into a Petri dish $(9 \mathrm{~cm}$ in diameter) containing a piece of polyethylene foam covered with a filter paper. The border of each disc was covered with hydrophilic cotton to prevent the mites escaping, and the foam was kept wet by the addition of distilled water. Ten adult females of $R$. indica or five adult females of A. largoensis were transferred to each leaf disc, representing one false repetition. Each treatment had 3 replications per concentration for a total of 30 and 15 mites, respectively. The units housing the mites were maintained inside growth chamber at $27 \pm 0.5^{\circ} \mathrm{C}$, $80 \pm 10 \% \mathrm{RH}$ and a $12 \mathrm{~h}$ photoperiod. The total of live and dead mites was determined after $24 \mathrm{~h}$. A mite was considered dead if it did not move at least the length of its body when touched by a fine brush (No. 000). For each acaricide, the concentrations that promoted $0-100 \%$ mortality of the $R$. indica specimens were determined. The same procedure was performed with A. largoensis; however, for the phytoseiid, only the five acaricides that proved to be toxic to $R$. indica were tested. During the bioassays, only castor bean pollen was used to feed the predators.

\section{Bioassay}

From the preliminary tests, 7-8 concentrations of each acaricide were established, ranging across the concentrations shown to result in 0-100 \% mortality of the mites. The control treatment corresponded to the immersion of the leaf discs in distilled water. The applications of acaricides and the evaluations were performed in a manner similar to those described for the preliminary tests. The bioassays had three replications for each 
concentration for a total of 30 adult females of $R$. indica and 15 adult females of A. largoensis, including the control. The entire procedure was repeated twice for a total 60 of and 30 mites per concentration for $R$. indica and A. largoensis, respectively.

Statistical analysis

The mortality data were submitted to a probit analysis (Finney 1971) after the correction of the mortality based on the control (Abbott 1925). The POLO-PC program (LeOra-Software 1987) was used to obtain the concentration response curves.

\section{Results and discussion}

The probit model fitted to mortality data of $R$. indica and A. largoensis $\left(\chi^{2}, p>0.05\right)$. The estimated concentrations that caused 50-90\% mortality ( $\mathrm{LC}_{50}$ and $\mathrm{LC}_{90}$, respectively) indicated that abamectin, fenpyroximate, milbemectin, spirodiclofen and propargite were the products most toxic to $R$. indica (Table 1). Estimates of the toxicity ratios for the $\mathrm{LC}_{50}$ showed that milbemectin was 6,028,000 times more toxic than spiromesifen and 11 times more toxic than abamectin. Estimates of the toxicity ratios for the $\mathrm{LC}_{90}$ indicated that milbemectin was 263,000,000 times more toxic than chlorfenapyr and only 1.44 times more toxic than abamectin. The slopes of the concentration-mortality curves ranged from 0.39 to 1.69 for the acaricides chlorfenapyr and abamectin, respectively.

The $\mathrm{LC}_{50}$ of the acaricides tested for A. largoensis ranged from 0.092 to $895.98 \mathrm{mg} / \mathrm{l}$ for abamectin and propargite, respectively, and the $\mathrm{LC}_{90}$ ranged from 2.23 to $761,637 \mathrm{mg} / \mathrm{l}$ for milbemectin and propargite, respectively (Table 2). The relative selectivity (lethal concentration of the predator/lethal concentration of the pest) for the $\mathrm{LC}_{50}$ ranged from 1.553 to 47,338 for fenpyroximate and milbemectin, respectively, and the relative selectivity for the $\mathrm{LC}_{90}$ ranged from 1.933 to 59,739 for fenpyroximate and abamectin, respectively.

The efficacy these acaricides for the control of $R$. indica in the field cannot be determined based on the $\mathrm{LC}_{90}$ values estimated in this study. However, it is possible to compare the toxicity of the acaricides evaluated for the organisms in this study. Abamectin, hexythiazox, fenpyroximate and spirodiclofen are currently registered for use in Brazil to control Aceria guerreronis Keifer (Acari: Eriophyidae) on coconut palm, which is the main crop attacked by $R$. indica in the country. The field doses recommended by the pesticides manufacturers for the control of A. guerreronis are $13.5-100 \mathrm{mg} / \mathrm{l}$ for abamectin and fenpyroximate, respectively. These doses are much higher than the values of the $\mathrm{LC}_{90}$ estimated in this work for $R$. indica. The concentrations recommended of abamectin and fenpyroximate for the control of A. guerreronis may also be efficient to $R$. indica on coconut palms. In contrast, the $\mathrm{LC}_{90}$ estimated for $R$. indica were higher than the field doses recommended of hexythiazox $(15 \mathrm{mg} / \mathrm{l})$ and spirodiclofen $(72 \mathrm{mg} / \mathrm{l})$ for controlling A. guerreronis.

Field tests to evaluate the effectiveness of acaricides to $R$. indica have been performed in India and the Middle East (Sarkar and Somchoudhury 1988; Jalaluddin and Mohanasundaram 1990, Jayaraj et al. 1991), with the best results being obtained using dicofol, dimethoate, endosulphan, ethion, monocrotophos, phosphamidon, quinalphos and phosalone. However, the use of several of these acaricides is prohibited in Brazil (Ministério de Agricultura and Pecuária e Abastecimento 2012) and in many other countries due to their high toxicities. Recently, Rodrigues and Peña (2012) evaluated various acaricides under 


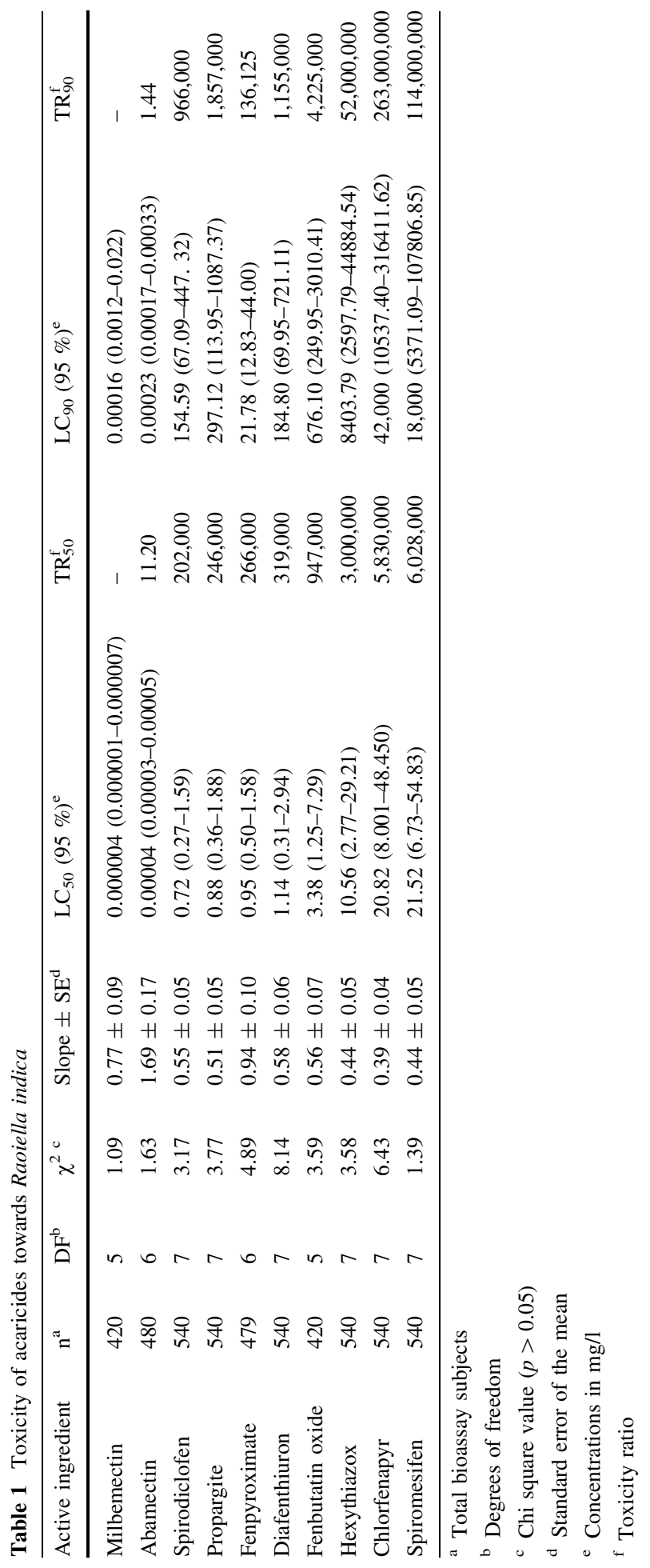




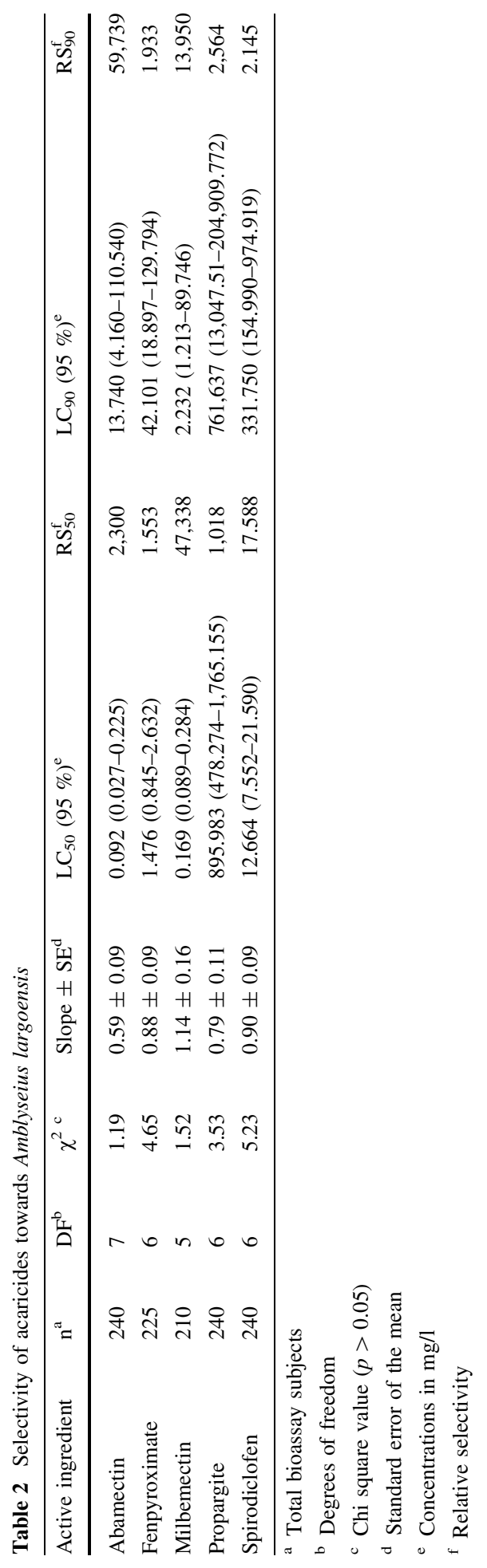


field conditions in Puerto Rico and Florida (USA), and they found that acequinocyl, dicofol and spiromesifen were effective in reducing the populations of $R$. indica.

In our study, abamectin and milbemectin were the products most toxic to $R$. indica; however, abamectin showed the largest angular coefficient among the acaricides evaluated. Therefore, this acaricide is the most promising due its rapid and efficient control of the pest (it causes more than $90 \%$ of mortality). The estimated $\mathrm{LC}_{90}$ of the products tested for A. largoensis indicated that abamectin and milbemectin were more toxic than fenpyroximate, propargite and spirodiclofen. Therefore, fenpyroximate, propargite and spirodiclofen are the most indicated for the management of $R$. indica because they are toxic to the pest and show a low toxicity to A. largoensis. Kim et al. (2005) evaluated the effect of abamectin on adult females of the predator Neoseiulus cucumeris (Oudemans) (Phytoseiidae) and concluded that this acaricide is very toxic to the phytoseiid. Noii et al. (2008) reported that the exposure to abamectin residues had a negative effect on Phytoseius plumifer (Canestrini \& Fanzago). In the other hand, several studies consider abamectin a product that does not cause harm to phytoseiids. Zhang and Sanderson (1990) concluded that abamectin is considerably more toxic to Tetranychus urticae Koch compared with Phytoseiulus persimilis Athias-Henriot. Ibrahim and Yee (2000) reported that the reproductive performance, longevity and sex ratio of Neoseiulus longispinosus (Evans) was not affected by abamectin, and these authors recommended the use of this product for the management of T. urticae. Irigaray et al. (2007) evaluated the mortality of Galendromus occidentalis (Nesbitt) and $P$. persimilis caused by abamectin and found that this product had a small residual effect on these predators. These conflicting results may be explained by the differences in the susceptibility between populations to abamectin (Hamedi et al. 2011) or due to the methodologies used during the cited studies.

Phytophagous mites introduce stylets into the plant tissues during the feeding and through this structure they extract the contents of the leaf mesophyll cells (Moraes and Flechtmann 2008). Raoiella indica normally feeds on Arecaceae plants that have leaves with a thick, fibrous epidermis and are covered with wax. Ochoa et al. (2011) studied how $R$. indica and other species of the same genus feed on coconut palms, banana trees, Heliconia and eucalyptus and they found that all species of Raoiella fed by inserting stylets into the stomata between the guard cells of all of the plant species studied. The authors also claimed that $R$. indica avoids the mechanical defenses of the plant by exploiting a structural weakness in the architecture of the leaf. The results of the present study showed that the acaricides that were most toxic to $R$. indica were abamectin and milbemectin, which are activators of chloride channels. These acaricides have a translaminar action in the plant and act via the contact and ingestion by the arthropods (IRAC 2012). The other products tested also act via contact and ingestion; however, they do not have a translaminar action in the plant and have different modes of action, acting on respiration (chlorfenapyr, fenpyroximate, fenbutatin oxide, propargite and diafenthiuron) and the growth and development (spirodiclofen and spiromesifen) of the mites (Yu 2008). Therefore, it is possible that the insecticide-plant-mite interaction has a greater effect in controlling of $R$. indica by abamectin and milbemectin, due to the translaminar action of these products and the feeding behavior of Raoiella (stomatal feeding).

Spiromesifen and spirodiclofen act as inhibitors of lipid synthesis and also by contact and ingestion by the arthropods (IRAC 2012). These acaricides cause high mortalities in immature forms and affect female fertility but are not as effective for adult mortality (Nauen et al. 2005; Marčić et al. 2009, 2011). However, Rodrigues and Peña (2012) found that spiromesifen at a dose of $0.145 \mathrm{mg} / \mathrm{l}$ was effective in controlling both the adult and immature forms of $R$. indica on coconut palms. With the introduction of $R$. indica in Brazil 
in 2009, the emergency registration of spiromesifen for the control of this mites on palm trees and Musaceae was conceded by the Ministry of Agriculture, Livestock and Supply for the period of September 2009 to September 2010. Chlorfenapyr, diafenthiuron and fenpyroximate have been reported to cause mortality in adult and immature mites and demonstrated intermediate toxicity among the products that were tested against $R$. indica in the present study. However, these compounds are not very toxic to Neoseiulus womersleyi (Schicha) (Kim and Seo 2001) and P. persimilis (Kim and Yoo 2002).

To date, no acaricide available on the Brazilian market is registered for control of $R$. indica in Brazil (Ministério de Agricultura and Pecuária e Abastecimento 2012), and the results obtained in this study may support the selection of acaricides to be used in the integrated pest management of $R$. indica. Further investigations should be conducted under field conditions to establish the appropriate time of year for the control and efficiency of these acaricides to manage properly the pest population and minimize the impacts on natural enemies.

Acknowledgments We thank the National Council for Scientific and Technological Development (CNPq), the Brazilian Agricultural Research Corporation (Embrapa-Roraima) and the Foundation for Science and Technology of the State of Pernambuco (FACEPE) for logistical and financial support. We thank Dr Gilberto J. de Moraes for reading the manuscript and for helpful comments.

\section{References}

Abbott WS (1925) A method of computing the effectiveness of an insecticide. J Econ Entomol 18:265-267

Carrillo D, Peña JE (2012) Prey-stage preferences and functional and numerical responses of Amblyseius largoensis (Acari: Phytoseiidae) to Raoiella indica (Acari: Tenuipalpidae). Exp Appl Acarol 57:361-372

Carrillo D, Peña J, Hoy MA, Frank JH (2010) Development and reproduction of Amblyseius largoensis (Acari: Phytoseiidae) feeding on pollen, Raoiella indica (Acari: Tenuipalpidae), and other microarthropods inhabiting coconuts in Florida, USA. Exp Appl Acarol 52:119-129

Carrillo D, Amalin D, Hosein F, Roda A, Duncan RE, Peña JE (2012) Host plant range of Raoiella indica (Acari: Tenuipalpidae) in areas of invasion of the New World. Exp Appl Acarol 57:271-289

Cocco A, Hoy MA (2009) Feeding, reproduction, and development of the red palm mite (Acari: Tenuipalpidae) on selected palms and banana cultivars in quarantine. Fla Entomol 92:276-291

Finney DJ (1971) Probit analysis, 3rd edn. Cambridge University Press, London

Flechtmann CHW, Etienne J (2004) The red palm mite, Raoiella indica Hirst, a threat to palms in the Americas (Acari: Prostigmata: Tenuipalpidae). Syst Appl Acarol 9:109-110

Hamedi N, Fathipour Y, Saber M (2011) Sublethal effects of abamectin on the biological performance of the predatory mite, Phytoseius plumifer (Acari: Phytoseiidae). Exp Appl Acarol 53:29-40

Hirst S (1924) On some new species of red spider. Ann Mag Nat Hist 14:522-527

Hoy MA (2012) Overview of a classical biological control project directed against the red palm mite in Florida. Exp Appl Acarol. doi:10.1007/s10493-012-9537-x

Ibrahim YB, Yee TS (2000) Influence of sublethal exposure to abamectin on the biological performance of Neoseiulus longispinosus (Acari: Phytoseiidae). J Econ Entomol 93:1085-1089

IRAC (2003) Insecticide Resistance Action Committee. Method $N^{\circ} 3$

IRAC (2012) Classificação do modo de ação dos inseticidas. Available in: http://www.irac-br.org.br/ Arquivos/Folder_Acao.pdf. Accessed 19 April 2012

Irigaray FJ, Zalom FG, Thompson PB (2007) Residual toxicity of acaricides to Galendromus occidentalis and Phytoseiulus persimilis (Acari: Phytoseiidae) reproductive potential. Biol Control 40:153-159

Jalaluddin SM, Mohanasundaram M (1990) Control of the coconut red mite Raoiella indica Hirst (Tenuipalpidae: Acari) in the nursery. Indian Coconut J Cochin 21:7-8

Jayaraj J, Natarajan K, Ramasubramanian GV (1991) Control of Raoiella indica Hirst (Tenuipalpidae: Acari) on coconut with pesticides. Indian Coconut J Cochin 22:7-9

Kane E, Ochoa R, Mathurin G, Erbe EF (2005) Raoiella indica (Acari: Tenuipalpidae), an island hopping mite pest in the Caribbean. Entomological Society of America, Annual Meeting, Fort Lauderdale, Florida 
Kim SS, Seo SG (2001) Relative toxicity of some acaricides to the predatory mite, Amblyseius womersleyi and the twospotted spider mite, Tetranychus urticae (Acari: Phytoseiidae, Tetranychidae). Appl Entomol Zool 36:509-514

Kim SS, Yoo SS (2002) Comparative toxicity of some acaricides to the predatory mite, Phytoseiulus persimilis and the twospotted spider mite, Tetranychus urticae. Biocontrol 47:563-573

Kim SK, Seo SG, Park JD, Kim SG, Kim DI (2005) Effect of selected pesticides on predatory mite, Amblyseius cucumeris (Acari: Phytoseiidae). J Entomol Sci 40:107-111

LeOra-Software (1987) POLO-PC: A user's guide to orobit or logit analysis. LeOra-Software, Berkeley

Marčić D, Ogurlić I, Mutavdžić S, Perić P (2009) The effect of spiromesifen on the reproductive potential of Tetranychus urticae Koch (Acari: Tetranychidae). Pestic Phytomed 24:203-209

Marčić D, Perić P, Petronijević S, Prijović M, Drobnjaković T (2011) Cyclic ketoenols: acaricides and insecticides with a novel mode of action. Pestic Phytomed 26:185-195

Ministério de Agricultura, Pecuária e Abastecimento (2012) Sistema de Agrotóxicos Fitossanitários. http://extranet.agricultura.gov.br/agrofit_cons/principal_agrofit_cons

Moraes GJ, Flechtmann CHW (2008) Manual de Acarologia Agrícola: acarologia básica e ácaros de plantas cultivadas no Brasil. Ribeirão Preto, Holos 288p

Nauen R, Schnorbach HJ, Elbert A (2005) The biological profile of spiromesifen (Oberon ${ }^{\circledR}$ ): a new tetronic acid insecticide/acaricide. Pflanzenschutz-Nachrichten Bayer 58:417-440

Navia D, Marsaro AL Jr, Silva FR, Gondim MGC Jr, Moraes GJ (2011) First report of the red palm mite, Raoiella indica Hirst (Acari: Tenuipalpidae), in Brazil. Neotrop Entomol 40:409-411

Noii S, Talebi K, Saboori A, Allahyari H, Sabahi Q, Ashouri A (2008) Study on side-effects of three pesticides on the predatory mite, Phytoseius plumifer (Canestrini \& Fanzago) (Acari: Phytoseiidae) under laboratory conditions. IOBC/WPRS Bull 35:146-151

Ochoa R, Beard JJ, Bauchan GR, Kane EC, Dowling APG, Erbe EF (2011) Herbivore exploits chink in armor of host. Am Entomol 57:26-29

Peña JE, Rodrigues JCV, Roda A, Carrillo D, Osborne LS (2009) Predator-prey dynamics and strategies for control of the red palm mite (Raoiella indica) (Acari: Tenuipalpidae) in areas of invasion in the Neotropics. Integr Control Plant Feed Mites IOBC/WPRS Bull 50:69-79

Rodrigues JCV, Antony LMK (2011) First report of Raoiella indica (Acari: Tenuipalpidae) in Amazonas State, Brazil. Fla Entomol 94:1073-1074

Rodrigues JCV, Irish BM (2012) Effect of coconut palm proximities and Musa spp. germplasm resistance to colonization by Raoiella indica (Acari: Tenuipalpidae). Exp Appl Acarol 57:309-316

Rodrigues JCV, Peña JE (2012) Chemical control of the red palm mite, Raoiella indica (Acari: Tenuipalpidae) in banana and coconut. Exp Appl Acarol 57:317-329

Sarkar PK, Somchoudhury AK (1988) Evaluation of some pesticides against Raoiella indica Hirst on coconut palm in West Bengal. Pesticides 22:21-22

Yu SJ (2008) The toxicology and biochemistry of insecticides. Taylor \& Francis Group, LLC $276 \mathrm{p}$

Zhang ZQ, Sanderson JP (1990) Relative toxicity of Abamectin to the predatory mite Phytoseiulus persimilis (Acari: Phytoseiidae) and twospotted spider mite (Acari: Tetranychidae). J Econ Entomol 83:1783-1790 